\title{
Pandemic perceptions: redefining the presence and value of one-to-one interactions and learning development in troublesome times
}

\author{
Heather Barker \\ University of Surrey \\ Robert Walsha \\ University of Surrey
}

Keywords: learning development perceptions; online learning; one-to-one interactions; hybrid learning; student engagement; Covid-19.

\section{The challenge}

Needing to react swiftly to the implications of lockdown, moving our Learning Development service (comprising Academic Skills and Development, and Maths and Statistics Advice) online felt relatively straightforward considering that virtual appointments had been offered pre-Covid. Despite significantly increasing one-to-one appointments to help students adjust, uptake was minimal from the original lockdown to the end of academic year 201920.

We recognised the important role that learning development (LD) should play in helping students to successfully transition to unexpected learning contexts. Anticipating potential factors affecting student learning engagement - ranging from technology to wellbeing concerns, as encapsulated by Gillis and Krull (2020) - our concerns included how we could:

- Maximise engagement with LD in a disrupted educational environment.

- Recreate and maintain informal and constructive relationships online for one-to-one interactions. 
An emerging consideration was whether we could capitalise on this learning disjuncture to encourage students to be more open to rethinking their relationship with and approaches to learning.

\section{The response}

A priority was ensuring that support and guidance were visible and, in the changed context, remained relevant and accessible (Raaper and Brown, 2020). Plans to enhance access to the service via a 'one-stop shop' module in the university's virtual learning environment (VLE) were accelerated by the pandemic, and this went live at the beginning of the $2020 / 21$ academic year. Having an online focal point undoubtedly raised the service's profile, not least with increased appointment bookings (which had already been picking up from summer 2020).

The initial lockdown provided a spur to simplify and make our supporting guidance on how to make the most of an appointment more visually engaging. Our aim was to better articulate learning expectations before, during and after sessions, driven by a desire to both improve clarity generally and address specifics to engaging successfully in the virtual/Covid context. This guidance somewhat recontextualised the instructional aspect of 'teaching presence' for effective online learning identified in the Community of Inquiry (Col) framework (Garrison et al., 2000). Whilst this framework primarily focuses on teaching, social and cognitive presence when engaging students asynchronously online, and did not directly inform the design of our interactions, we have nevertheless found it helpful to consider its relevance as part of the process of rationalising and making sense of our online synchronous experiences. We found that being clearer about the learning design, purpose and expectations of virtual one-to-ones helped to better define students' participatory role. Hosting the revised guidance on the VLE may have contributed to a noticeable increase in students' self-regulation (Zimmerman, 2002) in proactively managing their appointments, for example, cancelling or notifying us when unable to attend, in contrast with pre-Covid times, when failure to attend was more commonplace.

Additionally, critical to the success of our online appointments was a design imperative to create a safe, welcoming space for students in challenging times, one in which to explore 
concerns and (re)connect with learning experiences (Raaper and Brown, 2020). Positive connections seemed to be established, through email communication pre- and postsession and via informal conversations at the beginning of appointments, laying the foundations for constructive engagement. Sharing experiences of coping with the pandemic circumstances appeared to encourage empathetic and thoughtful exchanges, with students responding well to the idea that we were also learning significantly from these interactions. Perhaps dialogue was aided by seeing each other's names on screen; it certainly resonated in post-session feedback, in which students frequently mentioned their tutor by name, for example, 'Charles was really helpful and positive', 'Logan really helped me to see where I could improve sections of my writing' and 'Ororo was so patient and lovely to talk to'.

These factors may have empowered students' 'social presence', as per the Col framework (Garrison and Arbaugh, 2007; Cleveland-Innes, 2020), whereby establishing a sense of trust in the interaction elevated the quality of engagement, something the team consistently observed throughout 2020-21. The immersive online experience seemed conducive to creating a culture of mutual learning exchange, with the virtual environment feeling more equitable in comparison to its physical equivalent - less hierarchical due to the informality of the appointment setting when working from home (Murray et al., 2020). Conversely, appointments afforded greater privacy in contrast with the potential distractions experienced in the physical space on campus.

Students demonstrated increased self-efficacy (Zimmerman, 2000) in shaping conversations, for example, by bringing ideas and possible solutions and using the appointment to sound these out. Naturally, issues of confidence and uncertainty remained, but these were often matched by an increased ability to engage meaningfully and constructively, in some respects demonstrating the 'cognitive presence' aspect of the Col framework (Garrison and Arbaugh, 2007; Cleveland-Innes, 2020), possibly because of the enhanced sense of 'safe space'. This became a foundation upon which to explore Threshold Concepts (Meyer et al., 2010) related to the students' approaches to learning, given their greater openness to unpacking difficult aspects and willingness to change perceptions. The value of one-to-one interactions for engendering revelatory, breakthrough moments is well understood in LD, but online this seemed both more frequent and deepseated. It seems plausible, in the Covid context, that many may have valued our one-to- 
ones as a substitute for the loss of some of the more social dimensions of learning, such as impromptu peer support.

Evidence from post-appointment surveys confirms extremely positive experiences, most significantly in comments reflecting affective and emotional value (e.g., from content analysis, 'made to feel comfortable', 'listened to', 'stress-reducing', 'confidence-building', 'patient', 'understanding', 'kind', 'calming', 'reassuring', 'friendly', 'encouraging', 'nonjudgmental'). This appears to validate efforts to design an engaging, constructive online environment as a response to pandemic-induced disjunctures.

\section{Recommendations}

In making recommendations, we recognise the variations in LD practice across the sector. In our specific context, creating a strong VLE presence proved invaluable in enhancing accessibility and engagement, where hitherto service information had been dispersed and difficult to locate. The module was designed holistically, interlocking all aspects of service provision, resources and discussion forums; whilst focusing on appointments, the design of these ran hand-in-hand with considering the whole.

Going forward, it will be important for services to continue to evaluate their provision. Beyond the pandemic, or as we learn to better adapt within it, will our students continue to value interactions in such emotional and affective terms? We should aim to ensure we do not lose the focus, intensity and positivity of engagement experienced during the pandemic, while finding ways to reach learners who may have disengaged.

In the context of moving to dual forms of delivery (in our case prioritising online sessions but reinstating a face-to-face 'second tier' option), we would recommend a comparative analysis of provision to explore how positive experiences in each setting could be adapted to enhance the other.

As stated, we found it helpful to reconceptualise aspects of the Col theoretical framework to the synchronous one-to-one context as an exercise in rationalising our approach. Although there has been some research into using the framework for virtual one-to-ones 
(Stenbom et al., 2016), we would suggest that the pedagogy of online one-to-one LD in higher education is ripe for further investigation.

\section{References}

Cleveland-Innes, M. (2020) 'The Community of Inquiry theoretical framework, designing collaborative online and blended learning', in Beetham, H. and Sharpe, R. (eds.) Rethinking pedagogy for a digital age: principles and practice of design. $3^{\text {rd }}$ edn. New York: Routledge, Taylor \& Francis Group, pp.85-102.

Garrison, D.R. and Arbaugh, J.B. (2007) 'Researching the Community of Inquiry framework: review, issues, and future directions', Internet and Higher Education, 10, pp. 157-172. Available at: https://doi.org/10.1016/j.iheduc.2007.04.001 (Accessed: 25 August 2021).

Garrison, D.R., Anderson, T. and Archer, W. (2000) 'Critical inquiry in a text-based environment: computer conferencing in higher education', The Internet and Higher Education 2(2-3), pp. 87-105. Available at: https://doi.org/10.1016/S10967516(00)00016-6 (Accessed: 25 August 2021).

Gillis, A. and Krull, L.M. (2020) 'COVID-19 remote learning transition in Spring 2020: class structures, student perceptions, and inequality in college course', Teaching Sociology, 48(4), pp. 283-299. Available at: https://doi.org/10.1177/0092055X20954263 (Accessed: 25 August 2021).

Meyer, J.H.F., Land, R. and Baillie, C. (eds.) (2010) Threshold concepts and transformational learning. Sense Publishers: Rotterdam.

Murray, C., Heinz, M., Munday, I., Keane, E., Flynn, N. Connolly, C., Hall, T. and MacRuairc, G. (2020) 'Reconceptualising relatedness in education in 'Distanced' Times', European Journal of Teacher Education, 43(4), pp. 488-502. Available at: https://doi.org/10.1080/02619768.2020.1806820 (Accessed: 25 August 2021). 
Raaper, R. and Brown, C. (2020) 'The Covid-19 pandemic and the dissolution of the university campus: implications for student support practice', Journal of Professional Capital and Community, 5(3/4), pp. 343-349. Available at: https://doi.org/10.1108/JPCC-06-2020-0032 (Accessed: 25 August 2021).

Stenbom, S., Jansson, M. and Hulkko, A. (2016) 'Revising the Community of Inquiry framework for the analysis of one-to-one online learning relationships', The International Review of Research in Open and Distributed Learning, 17(3), pp.3653. Available at: https://doi.org/10.19173/irrodl.v17i3.2068 (Accessed: 25 August 2021).

Zimmerman, B.J. (2000) 'Self-efficacy: an essential motive to learn', Contemporary Educational Psychology, 25, pp. 82-91. Available at: https://doi.org/10.1006/ceps.1999.1016 (Accessed: 25 August 2021)

Zimmerman, B.J. (2002) 'Becoming a self-regulated learner: an overview', Theory into Practice, 41(2), pp. 64-70. Available at: https://doi.org/10.1207/s15430421tip4102 2 (Accessed: 25 August 2021)

\section{Author details}

Heather Barker is Teaching Fellow in Learning Development (Information Literacy) at the University of Surrey. Her current interests are in the holistic development of learners' academic and information literacies, with a particular focus on engaging with Generation $\mathbf{Z}$.

Robert Walsha is Head of Learning Development at the University of Surrey. His current areas of interest include exploring ways to rethink how learning development can more holistically engender genuinely responsible, informed and confident learners. 